\title{
Kreativitas Sebagai Literasi Media Televisi Di Era 4.0
}

\author{
Iin Soraya, Devy Putri Kussanti, Susilowati \\ Universitas BSI Jakarta
}

\begin{abstract}
Abstrak
Para pelaku industri penyiaran televisi dituntut memiliki kemampuan dalam membuat suatu strategi agar masyarakat tetap tertarik menyaksikan televisi. Literasi dapat diartikan secara sederhana sebagai "kemampuan", dalam konteks ini kemampuan televisi menciptakan strategi kreatif dalam content, informasi maupun berbagai program siaran yang inovatif. Kajian ini menggunakan metode penelitian dengan pendekatan penelitian kualitatif deskriptif, menggunakan metode wawancara dan observasi, sehingga dapat menjawab gambaran kreativitas seperti apa yang memungkinkan masyarakat minati saat ini. Hasil penelitian merupakan suatu pandangan yang menyatakan bahwa, content yang memiliki kreativitas menarik akan sangat menggugah minat masyarakat di era 4.0 dalam menonton televisi dan menjadikan segi/sudut pandang content yang paling utama. Hal tersebut dikarenakan content yang menyuguhkan banyak informasi apapun dan dikemas secara sederhana akan terlihat tetap menarik, terlebih jika menampilkan unsur budaya atau content lokal maka akan menambah nilai content tersebut.
\end{abstract}

Kata kunci: kreativitas, literasi media televisi, era 4.0

\section{Abstract:}

The television broadcast industry players are required to have the ability to make a strategy so that people remain interested in watching television. Literacy can be interpreted simply as "ability", in this context television capabilities create creative strategies in content, information and various innovative broadcast programs. This study uses a research method with a descriptive qualitative research approach, using interview and observation methods, so that it can answer the picture of what kind of creativity allows the public to be interested at this time. The result the study are a view that, content has interesting creativity will greatly arouse the interest of the people in era 4.0 in watching television and make the point or point of view of the most important content. This is because the content that present a lot of information and packaged in a simple way will look intersetung, especially if it displays elements of local culture or content that will add value to the content.

Keywords: creativity, television media literacy, era 4.0 


\section{Pendahuluan}

Empat puluh persen anak muda tidak lagi menonton siaran televisi melalui televisi fisik, tapi melalui gadget mereka. Menonton siaran televisi dengan cara streaming, menurut mereka merupakan pilihan yang baik dan efisien, khususnya mahasiswa yang mungkin tidak memiliki televisi di asrama atau tempat kos. Karena itu, cara ini menjadi salah satu cara antisipasi yang telah dilakukan oleh seluruh stasiun televisi yang tergabung dalam ATVSI. (Ishadi, 2018)

Revolusi Industri 4.0 ditandai dengan perubahan yang begitu cepatnya di era digital saat ini. Beberapa negara lain juga turut serta dalam mewujudkan konsep Industri 4.0 namun menggunakan istilah yang berbeda seperti Smart Factories, Industrial Internet of Things, Smart Industry, atau Advanced Manufacturing. Tujuan dari era 4.0 ialah untuk meningkatkan daya saing industri tiap negara dalam menghadapi pasar global yang sangat dinamis. Kondisi tersebut diakibatkan oleh pesatnya perkembangan pemanfataan teknologi digital di berbagai bidang. Era digital yang serba instan membuat televisi harus cepat beradaptasi dalam bersaing, karena dengan digitalisasi informasi apapun dengan mudah dapat diakses, tetapi dengan adanya era ini situasi yang ada hanya mengubah cara konsumsi masyarakat dalam menggunakan media televisi.

Hal ini menuntut stasiun televisi untuk terus menghadirkan inovasi, dalam kreativitas program tayangan, selain menarik untuk ditonton televisi tetap harus memperhatikan kualitas tayangan yang mendidik bagi masyarakat di segala usia. Meskipun dalam kenyataannya, masyarakat sangat menyukai program tayangan yang berdasarkan kisah nyata atau kehidupan keseharian dan bahkan mengenai konflik rumah tangga, tetapi pihak stasiun televisi juga harus dapat mengimbanginya dengan menyisipkan kalimat atau scene yang mendidik, mengajak pada kebaikan dan memberikan informasi yang sarat akan pengetahuan.

Saat ini, meskipun konten media tetap menggunakan fungsi dasar yang berisikan informatif, edukatif dan persuasif tetapi produksi program televisi di Indonesia mengalami krisis kreativitas, dimana pengembangan content media yang disuguhkan kepada masyarakat tidak murni berasal dari ide pokok tim produksi stasiun televisi yang bersangkutan. Banyaknya content media yang ditayangkan saat ini berasal dari ide atau gagasan yang berasal dari masyarakat, dimana pihak produksi program televisi mengadopsi content media lain tersebut yang kemudian dibuat kedalam berbagai program seperti talkshow, parodi, variety show, sinetron dan sebagainya. Pertanyaannya adalah, apakah media televisi saat ini telah bergeser kearah krisis kreativitas?.

Sebut saja salah satu content televisi "BoBoHo" yang disiarkan oleh TransTV pada hari Sabtu dan Minggu pukul 19.30, yang mana content 
tersebut merupakan pengembangan dari content yang ada di media sosial instagram, yang awalnya merupakan content yang dimiliki oleh akun instagram@bangijaltv. Untuk program acaranya, trend pihak TransTV saat ini lebih banyak mengadopsi content-content hingga talent yang berasal dari media sosial instagram, dengan kata lain acara TransTv banyak mengambil dari content media instagram yang sedang viral. Meskipun masyarakat terkesan menikmati dan bahkan mengidolakan program ataupun talent acara tersebut, tetapi apabila dikaji lebih dalam dari sisi kreativitas maka dapat dikatakan bahwa program tersebut hanya berisikan content yang sudah ada di akuninstagram@bangijaltv dan dengan kata lain terdapat sebuah hasil karya masyarakat (not self managing) dari pihak produksi atau pihak kreatif TransTv. Hanya saja pengemasannya lebih menarik karena ditayangkan dengan sistem audiovisual dan kemungkinan terdapat beberapa penambahan ide yang telah disepakati oleh pihak TransTv dan @bangijaltv.

Hal inilah yang menjadikan sebuah tantangan berat bagi pihak produksi atau kreatif di media televisi, untuk menggugah atau meningkatkan kembali kreativitas mereka dalam menciptakan content yang menarik, bermutu dan pastinya akan diminati masyarakat sehingga masyarakat lambat laun akan tertarik kembali untuk menonton televisi dan pihak media televisi pun tidak kalah bersaing dengan perkembangan di era 4.0 ini.

\section{Kajian Literatur \\ Media Massa}

Media massa menurut Cangara adalah "alat yang digunakan dalam penyampaian pesan dari sumber kepada khalayak (menerima) dengan menggunakan alat komunikasi mekanis seperti surat kabar, film, radio dan TV'. (Supriana, 2017)

Sedangkan Quail menyatakan bahwa media massa merupakan sumber kekuatan alat kontrol, manajemen, dan inovasi dalam masyarakat yang dapat didayagunakan sebagai pengganti kekuatan atau sumber daya lainnya. Media juga dapat menjadi sumber dominan yang dikonsumsi oleh masyarakat untuk memperoleh gambaran dan citra realitas sosial baik secara individu maupun kolektif, dimana media menyajikan nilai-nilai dan penilaian normatif yang dibaurkan dengan berita dan hiburan. (Supriana, 2017)

Straubhaar menyatakan bahwa:

Media massa mempunyai peran yang penting dalam memberikan pengaruh bagi keputusan yang berkaitan dengan kepentingan publik. Media juga mampu memunculkan isu yang baru yang bisa mempengaruhi berbagai kebijakan pemerintah, misalnya demonstrasi menolak kenaikan harga bahan bakar minyak. Maka, kebijakan media dalam mengatur agendanya, secara 
tidak langsung akan berdampak pula pada kebijakan pemerintah yang berkaitan dengan hidup masyarakat. (Esti \& Hartanti, 2015)

Tabel Sifat Fisik Dari Bentuk Media Massa

(Cetak, Radio dan Televisi)

\begin{tabular}{|c|l|}
\hline Jenis Media & \multicolumn{1}{|c|}{ Sifat } \\
\hline Cetak & $\begin{array}{l}\text { 1. dapat dibaca, dimana dan kapan saja } \\
\text { 2. dapat dibaca berulang-ulang } \\
\text { 3. daya rangsang rendah } \\
\text { 4. pengolahan bisa mekanik, bisa elektris } \\
\text { 5. biaya relatif rendah } \\
\text { 6. daya jangkau terbatas }\end{array}$ \\
\hline Radio & $\begin{array}{l}\text { 1. dapat didengar bila siaran } \\
\text { 2. dapat didengar kembali bila diputar kembali } \\
\text { 3. daya rangsang rendah } \\
\text { 4. elektris } \\
\text { 5. relatif murah } \\
\text { 6. daya jangkau besar }\end{array}$ \\
\hline 1. dapat didengar dan dilihat bila ada siaran \\
2. dapat dilihat dan didengar kembali, bila diputar kembali \\
3. daya rangsang sangat tinggi \\
4. elektris \\
5. sangat mahal \\
6. daya jangkau besar
\end{tabular}

Sumber: (Morissan, 2009)

\section{Era 4.0}

Menurut Kagermann, dkk "Istilah Industri 4.0 sendiri secara resmi lahir di Jerman tepatnya saat diadakan Hannover Fair padatahun 2011". (Prasetyo \& Sutopo, 2018). Industri 4.0 memang menawarkan banyak manfaat, namun juga memiliki tantangan yang harus dihadapi. Drath dan Horch berpendapat bahwa tantangan yang dihadapi oleh suatu negara ketika menerapkan Industri 4.0 adalah munculnya resistansi terhadap perubahan demografi dan aspek sosial, ketidakstabilan kondisi politik, keterbatasan sumber daya, risiko bencana alam dan tuntutan penerapan teknologi yang ramah lingkungan. (Prasetyo \& Sutopo, 2018)

Roser menyampaikan pendapatnya bahwa tanda kemunculan Industri 4.0 dimulai di Hannover, Jerman, saat diadakan Hannover Messe/Fair (merupakan sebuah pertemuan skala internasional dalam bidang industridan 
otomasi) di tahun 2011. Pada pertemuan tersebut, pemerintah Jerman mengumumkan kepada publik akan menggelontorkan dana sebesar 400 juta euro untuk penelitian dan pengembangan Industri 4.0. Ada yang berpendapat (yang nanti akan dijelaskan lebih detail) bahwa kemunculan Industri 4.0 ini akan membawa dampak yang besar pada bidang industri, ekonomi bahkan kondisi sosial masyarakat secara global. (Prasetyo \& Sutopo, 2017)

Lister, new media digunakan untuk mengarah ke hal-hal sebagai berikut:

1. Pengalaman tekstual yang baru: genre dan bentuk teks yang baru, hiburan dan pola konsumsi media (computer games, simulasi, special effect cinema)

2. Cara baru untuk merepresentasikan dunia: media yang selalu tidak bisa didefinisikan dengan jelas, menawarkan kemungkinan representasi dan pengalaman yang baru (lingkungan virtual, multimedia interactif)

3. Hubungan baru antara subyek (pengguna dan konsumen) dengan teknologi media: perubahan dalam penggunaan dan penerimaan image dan media komunikasi didalam keseharian dan dalam pemaknaan yang ditaruh dalam teknologi media.

4. Pengalaman yang baru dalam hubungannya dengan personifikasi, identitas dan komunitas: perubahan dalam pengalaman sosial dan personal dalam waktu, ruang dan tempat (dalam skala global dan lokal) yang memiliki implikasi terhadap cara manusia mengalami diri sendiri dan tempat manusia di dunia.

5. Konsepsi baru terhadap hubungan tubuh biologis dengan teknologi media: tantangan untuk menerima pembedaan antara manusia dan bukan, alami dan teknologi, teknologi, tubuh (dan media) sebagai pengganti secara teknologi, asli dan virtual. (Fitriyani, 2016).

\section{Kreativitas}

Kreativitas menurut Munandar "dikatakan bahwa kreativitas adalah kemampuan untuk menghasilkan/menciptakan sesuatu yang baru; kreativitas adalah kemampuan untuk membuat kombinasi-kombinasi baru yang mempunyai makna sosial”. (Richardo, Mardiyana, \& Saputro, 2014)

Selanjutnya Ali dan Asrori menyatakan bahwa kreativitas merupakan kemampuan seseorang untuk menciptakan sesuatu yang sama sekali baru atau kombinasi dari karya-karya yang telah ada sebelumnya menjadi suatu karya baru yang dilakukan melalui interaksi dengan lingkungannya untuk menghadapi permasalahan dan mencari alternatif pemecahannya melalui cara-cara berpikir divergen. (Richardo et al., 2014)

Menurut Slameto (Supriadi, 2003:17) mengatakan bahwa ciri-ciri kreativitas dapat dikelompokkan dalam dua kategori, kognitif dan non kognitif. Ciri kognitif diantaranya orisinilitas, fleksibelitas, kelancaran, dan elaborasi. Sedangkan ciri non kognitif diantaranya motivasi sikap dan kepribadian kreatif kreatif. Kedua ciri ini sama pentingnnya, kecerdasan yang tidak ditunjang dengan kepribadian kreatif tidak akan menghasilkan apapun. Kreativitas hanya dapat dilahirkan dari orang cerdas yang memiliki kondisi psikologi yang sehat. Kreativitas tidak hanya perbuatan otak saja namun variabel emosi dan kesehatan mental sangat berpengaruh terhadap 
lahirnya sebuah karya kreatif. Kecerdasan tanpa mental yang sehat sulit sekali dapat menghasilkan karya kreatif.

\section{Literasi Media}

Livingstone menjelaskan bahwa literasi media adalah kemampuan untuk mengakses, menganalisis, mengevaluasi dan mengkomunikasikan pesan dalam berbagai bentuk medium. Melalui pendidikan bermedia diharapkan seseorang dapat merefleksikan nilai-nilai pribadinya, menguasai ber- bagai teknologi informasi, mendorong kemampuan berpikir kritis, memecahkan masalah dan kreatif, dan mendorong demokratisasi. (Suwarto, 2018)

Menurut Ardianto "media literacy atau literasi media (kecerdasan media) tidak terlepas dari literate culture (budaya melek huruf)". Hal tersebut didasarkan dengan adanya kemampuan manusia dari jaman kejaman yang dapat menilai, menganalisa, mengakses dan mengembangkan potensipotensi yang ada dalam media massa. (Ardianto, 2014)

Dalam konteks perkembangannya, literasi media tidak akan dapat tercapai apabila tidak ada kemauan dari manusia itu sendiri untuk lebih mengembangkan kemampuan literasi medianya, hal tersebut dinamakan media literacy skill. Menurut Ardianto hal-hal yang mempengaruhi dari kemunculan dan tumbuhnya media literacy skill adalah:

1. Kemampuan dan keinginan untuk membuat kemajuan dalam memahami isi, memperhatikan dan menyaring informasi luar.

2. Pemahaman dan respek terhadap kekuatan pesan media.

3. Kemampuan untuk membedakan emosi ketika merespon isi dari media.

4. Pengembangan harapan yang dipertinggi dari isi media.

5. Pengetahuan konvensi "genre" dan kemampuan untuk menerima ketika terjadi penggabungan.

6. Kemampuan untuk berfikir kritis tentang pesan media. Tidak hanya kredibilitas sumber.

7. Sebuah pengetahuan bahasa internal dari berbagai media dan kemampuan untuk memahami dampaknya.(Ardianto, 2014).

Menurut Centre for Media Literacy dalam Nur menyatakan bahwa gerakan literasi media merupakan sebuah upaya yang bertujuan untuk memberdayakan masyarakatkhususnya khalayak media agar mempunyai keterampilan mengevaluasi dan berpikir kritis terhadap isi media. Beberapa keterampilan dan sikap kritis ini antara lain sebagai berikut;

1. Khalayak media memiliki kemampuan untuk mengkritik media.

2. Khalayak media memiliki kemampuan memproduksi media sendiri dan mereka mengkonsumsinya.

3. Khalayak memiliki kemampuan untuk mengajarkan tentang media, yaitu apakah media, bagaimana dampak buruk dan baiknya media dan bagaimana mensikapi media.

4. Khalayak mempunyai kemampuan untuk mengekplorasi sistem pembuatan media.

5. Khalayak memiliki kemampuan untuk mengeksplorasi berbagai posisi media yang sebenarnya bukan sebagai sebuah sistem yang netral dan bebas dari kepentingan. 
6. Khalayak mempunyai kemampuan untuk berpikir kritis terhadap isi media

Jadi singkatnya literasi media ini adalah pendidikan yang mengajari khalayak media agar memiliki kemampuan menganalisis pesan media, memahami bahwa media memiliki tujuan komersial/bisnis dan politik sehingga mereka mampu bertanggungjawab dan memberikan respon yang benar ketika berhadapan dengan media. (Suwarto, 2018)

Wiratmo dalam penelitiannya menyatakan bahwa;

Masyarakat cenderung menjadi khalayak pasif yang menjadi pasar, tak hanya produk media itu sendiri namun juga pasar bagi iklan yang menyertai konten tertentu. Tidaklah mudah bagi publik melawan kekuatan industri media yang padat modal dan berorientasi profit. Meskipun sejak era reformasi berbagai regulasi yang didedikasikan untuk melindungi kepentingan publik dari "serbuan" media digulirkan namun tak banyak merubah sajian yang menerpa publik. Lahirnya UU pers 1999 yang dilengkapi Kode Etik Jurnalistik, Undang-undang Penyi- aran lengkap dengan Pedoman Perilaku Penyiaran dan Standar Program Siaran (P3 dan SPS) yang dibuat Komisi Penyiaran Indonesia, Undang-undang ITE dan lain-lain belum sepenuhnya mampu menjamin hak publik memperoleh informasi dan hiburan sehat. Sejauh ini himbauan, desakan kepada pengelola media agar peduli terhadap kepentingan publik melalui konten yang mencerdaskan belum menunjukkan perkembangan memadai. (Suwarto, 2018).

\section{Media Televisi}

Dalam hasil penelitiannya, Ferry menyatakan bahwa;

Peran media massa, baik peran secara umum hingga yang praktis. Secara umum, bagi remaja peran media massa di antaranya memberikan informasi, hiburan, bujukan, pendidikan, sosialisasi, motivasi, bahan diskusi, memajukan kebudayaan ataupun integrasi. Secara khusus, bagi remaja peran media massa di antaranya mengetahui pesan dan bahaya produk atau kegiatan tertentu. Peningkatan perilaku positif remaja juga bisa dilakukan dan disebarluaskan melalui media massa ini. (Ferry, 2014).

Fungsi Televisi menurut Ardianto "sama dengan fungsi media massa lainnya (surat kabar dan radio siaran), yakni memberi informasi, mendidik, menghibur dan membujuk. Tetapi pada media televisi fungsi menghibur lebih dominan karena tujuan utama mayoritas masyarakat menonton televisi adalah untuk memperoleh hiburan dan selanjutnya untuk memperoleh informasi”. (Ardianto, 2014)

\section{Metode Penelitian}

Dalam metode penelitian ini, peneliti menggunakan metode penelitian dengan pendekatan kualitatif deskriptif. Proses penelitian ini membahas secara mendalam mengenai fenomena-fenomena, opini, perilaku, sikap, tanggapan dan keinginan seseorang dalam suatu kelompok. Metode observasi non-partisipan, wawancara dan studi kasus. Dimana tujuan dari penggunaan metode ini adalah untuk menjelaskan sedalam-dalamnya 
mengenai data yang didapatkan dari objek penelitian (kualitas) dan bukan banyaknya data (kuantitas). Deskripsi detail dari topik yang diteliti dipaparkan secara sistematis, faktual, dan akurat tentang fakta-fakta dan sifat-sifat populasi atau objek tertentu. Kemudian peneliti mengamati sikap dan perilaku dan kemudian menginterpretasikan dari sikap dan perilaku tersebut yang kemudian ditarik kesimpulan berdasarkan studi kasus mengenai kreatifitas media televisi saat ini yang masih kurang dalam hal menciptakan konten baru. Selain itu guna melengkapi kesimpulan, teknik wawancara dengan beberapa narasumber juga dilakukan, wawancara dilakukan dengan Divisi Creative Production Support yaitu diantaranya sebagai key informan Bapak Agung Raharjo dan sebagai informan yaitu Geby Siska Putri.

Hasil akhir dari penelitian kulitatif ini, bukan hanya sekedar menghasilkan data dan informasi yang sulit dicari melalui metode kuantitatif, tetapi juga harus dapat menghasilkan informasi-informasi bermakna, bahkan ilmu baru yang dapat digunakan untuk membantu mengatasi masalah dan meningkatkan taraf kehidupan manusia.

\section{Hasil Penelitian Dan Pembahasan}

Sebagai pekerja di bidang media televisi, Agung Raharjo menyatakan bahwa "saat ini Indonesia sudah masuk era 4.0 yaitu dimana era digital yang serba instan dan membuat televisi harus cepat beradaptasi bila tidak ingin kalah bersaing dengan media lainnya terlebih dengan media online. Teknologi telekomunikasi konvensional yang bersifat masif sekarang sudah mampu digabungkan dengan teknologi komputer yang bersifat interaktif. Sistem analog yang telah bertahan sekian puluh tahun akan segera tergantikan oleh sistem digital, dan implementasinya segera memunculkan fenomena baru yaitu konvergensi. Sederhananya, konvergensi adalah bergabungnya media telekomunikasi tradisional dengan internet sekaligus. Bersamaan dengan berlangsungnya konvergensi dibidang telematika, akan terjadi peralihan sistem penyiaran analog ke sistem penyiaran digital. Televisi digital (DTV/Digital Television) menggunakan modulasi digital dan kompresi untuk menyebarluaskan video, audio, dan signal data ke pesawat televisi. Kunci dari konvergensi adalah digitalisasi, karena seluruh bentuk informasi maupun data diubah dari format analog ke format digital sehingga dikirim ke dalam satuan bit (binary digit). Karena informasi yang dikirim merupakan format digital, konvergensi mengarah pada penciptaan produkproduk yang aplikatif yang mampu melakukan fungsi audiovisual sekaligus komputasi. Maka jangan heran jika sekarang ini komputer dapat difungsikan sebagai pesawat televisi, atau telepon genggam dapat menerima suara, tulisan, data maupun gambar tiga dimensi $(3 \mathrm{G})$. Dalam dunia penyiaran, 
digitalisasi memungkinkan siaran televisi memiliki layanan program seperti lainnya internet. Cukup dengan satu perangkat, seseorang sudah dapat mengakses surat kabar, menikmati hiburan televisi, mendengar radio, mencari informasi sesuai selera, dan bahkan menelpon sekalipun". Berawal dari keingintahuan masyarakat Indonesia yang semakin meningkat serta tingginya hasrat akan hiburan yang dapat mengesampingkan kepenatan maka tidak heran apabila media online sebagai media dengan jargon "dunia dalam genggaman atau telusuri apapun tanpa batas dan waktu" menjadi sebuah pilihan yang diminati masyarakat.

Agung Raharjo pun menambahkan "oleh karena itu pertelevisian Indonesia kini menghadapi tantangan untuk berkompetisi dalam menciptakan televisi digital agar arus informasi dapat diakses dimanapun dan kapanpun, sehingga tidak kalah dengan media digital lain. Hal ini menuntut stasiun televisi untuk terus menghadirkan inovasi, baik dalam program tayangan maupun dalam media penyiaran, salah satunya adalah dengan menyediakan akses untuk menonton siaran televisi secara online. Bahkan sekarang sudah $40 \%$ anak muda tidak lagi menonton siaran televisi melalui televisi fisik, tapi melalui gadget mereka".

Penggunaan media online tidak terlepas dari kemampuan yang dimiliki oleh masyarakat Indonesia, dimana seluruh masyarakat kini telah melek teknologi dan informasi. Dengan kata lain media televisi sudah harus melihat fenomena bahwa masyarakat Indonesia kini semakin kristis, haus informasi dan hiburan serta mencari alternatif media lainnya untuk menggali lebih dalam lagi mengenai hal-hal yang ingin mereka ketahui. Pernyataan tersebut dapat dikategorikan kedalam sebuah literasi media atau tumbuhnya kemampuan dalam literasi media.

Persaingan yang dihadirkan oleh media online sudah seharusnya disikapi oleh media televisi dengan meningkatkan dan mengembangkan contentcontent yang menarik, informatif, persuasif, edukatif, menghibur dan yang utama adalah berisikan content yang kreatif sehingga akan menarik perhatian penonton untuk kembali mengkonsumsi televisi dibandingkan media online. Dari segi kreativitas, media televisi saat ini terlihat tergerus oleh era 4.0 yang kian hari semakin menampilkan kreativitas yang tinggi baik dari segi content, tampilan, talent, ide yang fresh dan orisinal serta berbagai hal lainnya.

Ciri-ciri kreativitas dapat dikelompokkan dalam dua kategori, kognitif dan non kognitif. Ciri kognitif diantaranya orisinilitas, fleksibilitas, kelancaran, dan elaborasi. (Slameto, 2003)

Berdasarkan penjelasan di atas kreativitas merupakan sesuatu yang orisinil dan fleksibel. Seringkali juga kreativitas dianggap sebagai kemampuan yang dimiliki oleh seseorang dalam menciptakan ide ataupun gagasan yang baru dan layak guna bagi masyarakat. Hal inilah yang 
menggaris bawahi adanya sebuah dorongan bahwa para pekerja di stasiun televisi terlebih yang berada dalam bagian pengembangan program dan perencanaan content agar dapat meningkatkan dan mengembangkan kemampuan kreativitasnya dalam menciptakan sebuah program dengan content yang menarik, fresh dan tentunya kreatif. Perkembangan program televisi saat ini menyajikan content yang banyak mengambil dari akun media sosial seperti instagram yang sedang viral kemudian diangkat menjadi program televisi. Dari sudut pandang kreativitas, hal tersebut dianggap sebagai mengadopsi sesuatu hal yang baru (newest) bukan menciptakan sesuatu hal yang orisinal. Berkenaan dengan kreativitas yang bersifat orisinal, tidak telepas dari kemampuan yang dimiliki media televisi dalam berfikir kreatif tetapi dalam konteks yang sederhana atau cakupan keseharian.

Hal diatas diperkuat dengan penjelasan dari Geby Siska Putri "kreativitas yang menarik minat masyarakat di era 4.0 saat ini ialah dengan adanya content yang dikemas secara sederhana tetapi menarik seperti tayangan Sinetron Dunia Terbalik dan Tukang Ojek Pengkolan, yang hanya mengangkat kisah keseharian dari suatu daerah yang lebih dekat dengan masyarakat atau program yang ditargetkan untuk ibu rumah tangga, contohnya seperti program yang menceritakan tentang kisah nyata dalam rumah tangga dan dibumbui oleh perselingkuhan, itu salah satu contoh program yang sangat disukai oleh ibu-ibu rumah tangga seperti Ungkap di SCTV". Kemudian Geby Siska Putri melanjutkan "trend ide lokal saat ini sangat menarik minat masyarakat, karena masyarakat Indonesia beberapa tahun terakhir sudah mengalami kejenuhan dengan diperlihatkan tayangantayangan yang hanya menonjolkan kecantikan, kekayaan dan kekuasaan. Saat ini masyarakat Indonesia terutama anak muda butuh tayangan yang mendidik dan menampilkan unsur budaya yang ada didalamnya, seperti tayangan Tukang Ojek Pengkolan dan Dunia Terbalik yang menerapkan konsep content lokal dalam penayangannya. Content lokal sangat digemari karena mudah dalam segi bahasa serta komunikasinya secara audio visual"

Media televisi dalam konteks minim kreativitas terlihat dari adanya content yang tidak orisinal, yang hanya mengadopsi dari berbagai content yang sedang viral di media sosial. Hal ini diperkuat dengan pernyataan Agung Raharjo yang menyatakan bahwa "program televisi saat ini sudah tidak lagi berkualitas dalam segi content. Sejatinya, acara televisi itu wajib punya kualitas dan tentunya mendidik. Sayang, untuk menarik banyak penonton terkadang banyak stasiun televisi menghalalkan segala cara untuk mendapat rating tertinggi. Salah satunya adalah dengan membuat sensasi". Beliau pun menambahkan "terdapat 7 acara televisi yang pernah ditegur oleh KPI (Komisi Penyiaran Indonesia) karena seringkali membuat sensasi, diantaranya ialah: D'academy, Fesbuker, Music Dahysat, OVJ, Music Inbox, 
Mama Amy, dan Bukan 4 Mata. Program televisi saat ini menyajikan program-program masa kini serta modern tapi keluar dari batas peraturan yang sudah ditentukan". Dari sini terlihat bahwa pihak media televisi hanya mengutamakan rating ataupun keuntungan semata dengan adanya program baru dan mengesampingkan kreativitas dalam penyuguhan content yang bermanfaat dan menarik bagi penonton/masyarakat Indonesia.

Sebagai contoh dari minimnya kreativitas pihak media televisi ialah dengan adanya tindakan mengadopsi beberapa content media sosial yang dijadikan sebuah program di stasiun televisi mereka. Memang jika dilihat dari segi keuntungan dan rating serta keselarasan dengan perkembangan teknologi informasi di era 4.0 pihak media televisi telah menggunakan media online dan media sosial dengan baik, dengan adanya live streaming pada saat siaran, siaran televisi secara online, berita online daring yang berbentuk situs web berita, bahkan setiap stasiun televisi atau program televisi kini memiliki akun media sosial tersendiri dan lain sebagainya. Tetapi jika dilihat dari segi kreativitas content program yang ditayangkan, beberapa media televisi hanya mengandalkan ide yang sudah ada di media online ataupun di media sosial. Hal inilah yang membuat penilaian terhadap media televisi condong kearah krisis kreativitas.

Berdasarkan hasil wawancara dengan Geby Siska Putri "contoh kasus terbaru saat ini ialah pengangkatan ide content yang ada di Instagram @ bangijaltv menjadi sebuah program acara yang ditayangkan oleh TransTV yakni Boboho". Kemudian Geby Siska Putri pun menambahkan "trend program televisi yang diambil dari content media sosial yang sedang viral seperti program Boboho dari instagram @bangijaltv merupakan suguhan hiburan di era 4.0, dengan penambahan ide yang tidak monoton dari pihak stasiun televise". Agung Raharjo menambahkan "walaupun content diambil dari media sosial sudah seharusnya tidak memundurkan kreativitas insan pertelevisian, justru memotivasi mereka untuk berkreativitas yang lebih PEKA lagi dan diolah secara modern serta lebih dikembangkan kembali dengan penambahan ide-ide yang segar".

\section{Simpulan}

Dalam penelitian ini penulis memaparkan hasil penelitian yang didapatkan selama mengkaji beberapa literature dan menganalisa hasil dari wawancara "kreativitas sebagai literasi media televisi di era 4.0". Berdasarkan hasil penelitian, maka ditemukan jawaban dari gambaran kreativitas media televise di era 4.0, yakni: Perkembangan televisi saat ini kebanyakan menyajikan program yang sudah tidak lagi berkualitas dalam segi content. Terbukti masih terdapat beberapa program acara yang ditegur oleh KPI. Di era digital ketika sebagian besar persebaran informasi 
berlangsung di dunia maya, industri pertelevisian menghadapi persaingan dengan media-media online yang relatif lebih mudah diakses.

Perkembangan televisi dan dunia penyiaran di era 4.0 akan berubah seiring berkembangnya teknologi komunikasi dan informasi, serta pola konsumsi masyarakat terhadap media. Content yang kreatif dan menarik minat masyarakat di era 4.0 dilihat dari segi ide lokal dan berisikan mengenai cerita keseharian masyarakat. Hal ini dapat dilihat dari salah satu tayangan sinetron Dunia Terbalik dan Tukang Ojek Pengkolan.

Trend ide lokal saat ini sangat menarik minat masyarakat, karena masyarakat Indonesia sudah mengalami kejenuhan maka masyarakat butuh dengan tayangan yang mendidik dan menampilkan unsur budaya atau content lokal. Program Boboho dari stasiun televisi TransTV merupakan content yang diadopsi dari media sosial instagram@Bangijaltv yang sedang viral saat ini. Meskipun content diambil dari media sosial, diharapkan tidak memundurkan kreativitas insan pertelevisian, tetapi Justru memotivasi untuk berkreativitas yang lebih PEKA lagi dan diolah secara modern serta dikembangkan kembali content tersebut.

\section{Referensi}

Esti, L., \& Hartanti, P. (2015). Kebijakan Media Televisi Di Era Media Baru. Jurnal Interact, 4(1), 37-46. Retrieved From Http://Ojs.Atmajaya.Ac.Id/Index.Php/Fiabikom/Article/Download/730/5 $\underline{90 .}$.

Ferry. (2014). Media Televisi Kajian Peran Media Massa Dan Pengaruhnya Bagi Remaja. Peran Media Massa, 14(1), 12. Retrieved From Http://Dinus.Ac.Id/Repository/Docs/Ajar/Article5

Fitryarini, I. (2016). Literasi Media Pada Mahasiswa Prodi Ilmu Komunikasi Universitas Mulawarman. Jurnal Komunikasi, 8(1), 51-67. Retrieved From

Https://Www.Researchgate.Net/Publication/320842107_Literasi_Media _Pada_Mahasiswa_Prodi_Ilmu_Komunikasi_Universitas_Mulawarman I_Fitryarini_Jurnal_Komunikasi_8_1_51-67

Helys, M. R. \&, \& Handayani. (2016). Efektifitas Komunikasi Dalam Penggunaan Media Sosial Instagram Sebagai Media Komunikasi Di Kalangan Mahasiswa Fakultas Ilmu Sosial Dan Ilmu Politik Universitas Surakarta. Jurnal Penelitian Dan Kajian Ilmiah Fakultas Ekonomi Universitas Surakarta, 14(2085-2215), 19-24. Retrieved From 
$\underline{\text { Http://Ejurnal.Net/Portal/Index.Php/Smooting/Article/Download/1722/1 }}$ $\underline{603}$

Sk, Ishadi (2018), Media Televisi Hadapi Tantangn Di Era Digital (Gloria/ Https://Www.Ugm.Ac.Id/Id/Berita/11575-

Industri.Televisi.Hadapi.Tantangan.Di.Era.Digital).

Pertiwi, R. (2014). Aktivitas Komunikasi Tradisinyawerpada Proses Pernikahan Adat Sunda Di Kota Bandung (Studi Etnografi Komunikasi Mengenai Aktivitas Komunikasi Dalam Tradisinyawer Pada Proses Pernikahan Adat Sunda Di Kota Bandung) Ratu Aulia Pertiwi Nim: 41810087. Jurnal Unikom. Retrieved From Http://Elib.Unikom.Ac.Id/Files/Disk1/691/Jbptunikompp-GdlRatuauliap-34536-11-Unikom_R-L.Pdf.

Prasetyo, H., \& Sutopo, W. (2017). Perkembangan Keilmuan Teknik Industri Menuju Era Industri 4.0. Seminar Dan Konferensi Nasional Idec, (Issn: 2579-6429), 2579-6429. Retrieved From Http://Idec.Industri.Ft.Uns.Ac.Id/WpContent/Uploads/2017/11/Prosiding2017 Id069.Pdf.

. (2018). Industri 4.0: Telaah Klasifikasi Aspek Dan Arah Perkembangan Riset. Jurnal Teknik Industri Undip, $13 . \quad$ Retrieved From Https://Ejournal.Undip.Ac.Id/Index.Php/Jgti/Article/Viewfile/18369/12 $\underline{865}$

Supriana, H. (2017). Pengaruh Media Massa Terhadap Citra Partai Politik. Lampung. Retrieved From Http://Repository.Radenintan.Ac.Id/3055/1/Skripsi_Lengkap_Herri.Pdf.

Suwarto, D. (2018). Gerakan Literasi Media Di Indonesia. Rumah Sinema. Retrieved From Https://Www.Researchgate.Net/Publication/324245487_Gerakan_Liter asi_Media_Di_Indonesia. 